\title{
Construction and application of an indicator system to assess the ergonomic performance of large and medium-sized construction companies
}

\author{
Isabela Xavier Barbalho Bezerra ${ }^{\mathrm{a}}$ and Ricardo José Matos de Carvalho ${ }^{\mathrm{b}}$ \\ ${ }^{a}$ Masters student in Production Engineering, GREPE, UFRN, Campus Universitário, Lagoa Nova, Natal, RN, \\ Brasil. \\ ${ }^{\mathrm{b}}$ Doctor in Production Engineering, Professor of Production Engineering, GREPE, DEP, PEP, UFRN, Campus \\ Universitário, Lagoa Nova, Natal, RN, Brasil.
}

\begin{abstract}
This article proposes a system of indicators to evaluate the performance of companies in ergonomics for buildings. The system was developed based primarily on studies related to the performance evaluation of the construction industry and on Brazilian standards of ergonomics and work safety and had also the contribution of national and international indicators related to ergonomics, work safety, quality, sustainability, quality of work life and to organizational behavior. The indicators were named, classified and their components were assigned to compose the theoretical model SIDECE - System of Performance Indicators in Ergonomics for Building Construction (as for the Portuguese acronym), serving the major goals of ergonomics: health, safety and workers' satisfaction and production efficiency. The SIDECE is being validated along with the building construction companies in the city of Natal, Brazil, whose practical results, deriving from the application of instruments to collect field data, are under process, to be presented on the occasion of the 18th World Congress on Ergonomics. It is intended that the SIDECE be used by building construction companies as a support tool for excellence management.
\end{abstract}

Keywords: Ergonomics, Indicators, Performance, Building construction, SIDECE.

\section{Introduction}

The Brazilian construction industry, particularly the sector of building construction, has no system of performance evaluation that takes into account the binomial production and health. Ergonomics seeks to equate their goals in aspects of production and health ${ }^{[1]}$, with an understanding that the workers' safety and health are factors of production and that the way of production creates an impact on the workers' health, safety and quality of life.

This article aims at presenting the theoretical model SIDECE - System of Performance Indicators in Ergonomics for Building Construction, which was developed to evaluate the performance of companies in ergonomics for large and medium-sized buildings in the city of Natal. The development of this system occurred from a literature review and was based on regulatory standards for ergonomics (NR-17) and civil construction (NR-18) in Brazil, isolated indicators, systems of sustainability indicators, quality of work systems of indicators and general and specific systems of indicators related to organizational performance for the construction industry.

It appears that the main systems available to evaluate the performance of organizations neglect many aspects of the scope of ergonomics. This gap imposes a partial understanding by managers of organizations with respect to their performance, which could compromise their strategies, survival and longevity and unnecessarily burden the organization.

The development of SIDECE adopted the following process: identification of indicators and standards available in the literature, selection of relevant indi- 
cators, creation of new indicators, classification of indicators, appointment of indicators and assignment of the indicators components.

The goal is that SIDECE indicators enable managers of construction sites to develop a diagnosis of the level of expertise in ergonomics of the companies, as these indicators allow the items of absence or scarcity of ergonomics to be identified and permit to establish an ergonomic program of actions based on them.

\section{Civil construction industry in Brazil}

The civil construction companies in Brazil face a situation of strong expansion of the buildings construction market, encouraged by the housing program "Minha Casa Minha Vida" ("My House My Life") from the Federal Government of Brazil, with the approach of two of the major sporting events in the world (the 2014 FIFA World Cup and the Olympics in 2016), and by the intense competitiveness of the sector, in which factors related to quality and prices of buildings are crucial.

The quality of the buildings and the sale price of the units have to do with the rational management of construction processes and manpower.

Historically, the civil construction industry in Brazil, specifically in the building sector, is regarded as producing high levels of waste and work accidents. However, there are no reliable overall indicators of waste in the sector, although there are systems of specific performance indicators developed and applied in some companies, in a local way, that function by assisting the management system.

The official statistics of work accidents in Brazil are not reliable, since there is underreporting of such events by the construction companies. Despite the underreporting, in 2009 the construction industry figured as one of the sectors with the highest number of accidents in Brazil, with a total of 54,142 accidents, or $7.48 \%$ of all work accidents at national level, only behind the sectors of Trade and Repair of Motor Vehicles $(98,096 ; 13.56 \%)$, Food and Beverage Industry $(66,554 ; 9.20 \%)$ and Health and Social Services $(57,606 ; 7.96 \%)^{[2]}$.

The building construction sector in Brazil lacks a global system of indicators that will enable the companies to obtain a diagnosis that encompasses both performance factors related to technical system and human factors.

\section{Measurement systems of organizational performance}

The available systems of performance indicators, such as the Balanced Scorecard (BSC), among others, are strongly focused on aspects related to organization and technology, but little attention is given to personnel or human factors, so that measuring the organizational excellence from these settings will result in a partial diagnosis, not as accurate as a new configuration that also incorporates the human factors adequately.

"The measurement system strongly affects the behavior of people inside and outside the company. If you want to survive and thrive in the information age, companies must use systems of management and performance measurement derived from their strategies and capabilities ${ }^{[3]}$."

A technical and scientific literature does not have specific indicators of ergonomics for building construction, i.e., there is not a system of indicators to evaluate the ergonomic performance of organizations and especially the ones of the building construction industry.

"For the ergonomic practices to find shelter in organizations in the form of systematic practice, it is necessary, fundamentally, the identification and definition of 'ergonomic' indicators," argues ${ }^{[4]}$.

From the mid-1980s, in the construction industry there was a growing interest in quality management and, consequently, the implementation of measurement systems. This move reflected the emphasis that was given to quality in other sectors of the economy and throughout the world, but also resulted from changes that were affecting the industry, among which stood out: the globalization of the economy, the shortage of construction funds, greater demands from customers about the quality and standard of buildings and also a greater degree of organization and manpower claims.

\section{4. (Macro)Ergonomics}

"Ergonomics (or human factors) is the scientific discipline concerned with the understanding of interactions among humans and other elements of a system, and the profession that applies theory, principles, data and methods to design in order to optimize human well-being and overall system performance" ${ }^{[5]}$.

Ergonomics as an area of professional practice is as a space where "professionals apply the technology of human-system interface for the design, analysis, 
testing and evaluation, standardization and control systems. The overall goal of the discipline is to improve the human condition, including health, safety, comfort, productivity and quality of life" [6].

For ${ }^{[7]}$ Hendrick and Kleiner, "macroergonomics deals with the analysis and design of work systems."

Ergonomics, therefore, is concerned with optimizing work systems, taking into account the economical (quality, production, productivity, efficiency, effectiveness) and health aspects (work accidents, work diseases, work absenteeism, workload) as a whole. This involves the knowledge of proactive and reactive indicators in organizational, technological and personnel aspects, which express the investments made, the actions taken and the human and material impacts generated by the work system.

\section{Materials e methods}

This research has an applied nature, for it aims to generate knowledge for practical application aimed at solving specific problems and involves local interests and truths ${ }^{[8]}$.

\subsection{Location and scope of the study}

This research is being applied to large and medium-sized building construction companies in the city of Natal, Brazil.

According to the Brazilian Chamber of Construction Industry (CBIC - as for the Portuguese acronym), the conceptualization by the number of workers employed in working companies in the industry of construction sets the size of these companies.

"The use of this criterion is justified because this is the most prevalent one in most law systems, government agencies and research institutions in the country" [9].

The ranges of size classification of enterprises adopted by CBIC, according to the number of employees, are as follows:

a) up to 19 employees - Microcompany;

b) from 20 to 99 employees - Small Company;

c) from 100 to 499 employees - Medium-sized Company;

d) 500 or more employees - Large Company.

Therefore, this research covers building construction companies that have 100 (one hundred) or more employees.
According to the website of the Federation of Industries of Rio Grande do Norte (FIERN), there are two large companies and 34 medium-sized companies in building construction in the city of Natal, state of Rio Grande do Norte. ${ }^{[11]}$ (FIERN).

\subsection{Applied Research: Development of SIDECE (Modeling Process)}

To develop the System of Performance Indicators in Ergonomics for Building Construction (SIDECE) proposed here, there was a literature research to find the key indicators and understand how they could be used to improve the performance of organizations.

There was a selection of relevant indicators to the ergonomic study in question, taking into consideration the possible applicability and help improving the management of the construction of multifamily buildings.

The development of SIDECE had as reference the following individual indicators or systems of indicators:

- The System of Indicators for Quality and Productivity in Civil Construction - SISIND ${ }^{[11]}$;

- The System of Indicators of Performance for Production Management in Residential Edifications Enterprises ${ }^{[12]}$;

- The existing indicators on the Norm of the Ministry of Labor and Employment $n^{\circ} 18^{[13]}-$ NR-18 (Work Conditions and Environment in the Construction Industry);

- The existing indicators on the Norm of the Ministry of Labor and Employment $n^{\circ} 17^{[14]}-$ NR-17 (Ergonomics);

- The Indicators of Ergonomic Costs established by studies on Macroergonomics ${ }^{[7]}$;

- The Indicators proposed by Nogueira ${ }^{[4]}$;

- The Measurement Scales of Organizational Behavior $^{[15]}$; [16];

- The Indicators of Competences Management

- The Indicators of ${ }^{[17]}$ Gross National Happiness;

- The Indicators of Quality of Life at Work ${ }^{[18]}$;

- The indicators in Brazilian Norm $n^{\circ}$ 14280:2000

[19], from the Brazilian Association of Technical Norms (ABNT);

- The OHSAS 18001:2001 [20] - Occupational Health and Safety Advisory Services.

- The Work Safety Indicators ${ }^{[21]}$;

- The Global Reporting Initiative (GRI) ${ }^{[22]}$, Sustainability Report. 
The knowledge of these indicators or systems of indicators was essential, because it allowed a mapping of the key indicators and existing systems and facilitated the process of developing a system of specific indicators, proper and adequate to the main goals of ergonomics, oriented to buildings construction, as proposed by the SIDECE presented here.

\subsection{Steps of the indicators development}

The development of SIDECE had the following steps:

1) Studies and exploratory research: in this phase of SIDECE development, literature, documents and regulations researches were conducted, in order to clearly define the scenario in which the performance indicators were included, what are the main authors and documents that focused on the subject and what indicators and systems of indicators are better known and used in construction and other economic sectors, as well as ergonomic aspects that suggested the construction of the indicator.

2) Selection of isolated indicators and systems of indicators and creation of new ones from the exploratory research: this phase was composed of mapping, analysis and definition of indicators relevant to SIDECE, according to their relevance to ergonomics and building construction. New indicators were also created from these ergonomic norms and suggested the construction of the indicator.

3) Classification of available systems and indicators in categories: in this phase, we established categories of ergonomics, to which each selected indicator would be allocated. The categories of established ergonomics for the classification of the indicators were: the External Environment or Context; Environmental conditions of work; Work efficiency; Machinery and Tools of work sites; Work sites furniture; Work organization; Workers' satisfaction; Workers' Health and Safety; and Transportation of materials.

4) Modeling of SIDECE Indicators: setup of required components of each indicator selected for the system as well as methods of data collection and/or formula calculations for each one, which constituted a protocol for collecting performance data, necessary for the attainment of indicators, called SIDECE Model.

a) Modeling 1 -development of conceptual General SIDECE Model (table 1);

b) Modeling 2 - development of Detailed (operational) SIDECE Model: this model was developed and concerns the data collection instrument in build- ing construction companies, which are part of the performance indicators. This instrument will undergo its first changes, from the results of the research which is in progress (section $\underline{c}$ below) and possibly different changes will take place after testing, from which the instrument will be definitely applied;

c) Research for exploration and verification of acceptance and managers' opinions (civil engineer, engineer work safety and safety technician) based on the generic model: before heading for testing, validation and application of detailed direct SIDECE Model (Modeling 2, letter $\underline{b}$ ), it was decided as a precaution, to consult these professionals as to whether they produced indicators, what these indicators were and what was, in their perception, the relevance and applicability of the indicators that had been anticipated in the SIDECE Model. For such, we developed a specific tool called "Preliminary protocol to map the SIDECE indicators in the organization", composed of two tables to be filled by the managers. These tables are structured as follows:

Table 1: Name of indicator; Purpose of the indicator; The manager uses this indicator; Reason to use or not the indicator; Suggestions.

Table 2: Name of indicator; Purpose of the indicator; Classify the importance of the indicator (1unimportant, 2-little important, 3-undecided, 4important and 5-very important); Justify the choice.

5) Testing: concerns the phase designed to test the detailed SIDECE Model tool.

6) Application: direct research phase, corresponding to the collection of field data in order to produce performance indicators, using the instrument tested.

7) Data processing and analysis of the results: phase of the survey responses, when the results of the indicators collected in the field will be processed and analyzed. In this phase various types of responses will be generated, such as: comparisons between works/construction companies, the appearance or non-appearance of a construction company in which its processes will be ergonomically models for the other ones in market; discussions and debates may be initiated; several graphics and tables will be generated; among many other results.

\section{Proposed SIDECE Model}

\subsection{General SIDECE Model}

Table 1 shows the generic SIDECE model, composed by the considered relationship of categories (column 
1), by the indicators themselves (column 2 ), by the form or data collection instrument (column 3) and by their classification as to the opportunity to use the indicator (column 4).

Table 1

SIDECE Indicators

\begin{tabular}{|c|c|c|c|}
\hline $\begin{array}{l}\text { Category of Indi- } \\
\text { cators }\end{array}$ & Indicators & $\begin{array}{l}\text { Form or instrument of Data } \\
\text { Collection }\end{array}$ & $\begin{array}{l}\text { Classification } \\
\text { (Proactive or reactive) }\end{array}$ \\
\hline \multirow{4}{*}{$\begin{array}{l}\text { External environ- } \\
\text { ment or context }\end{array}$} & - Evaluation of suppliers and contractors & Form & Proactive \\
\hline & $\begin{array}{l}\text { - Degrading Impacts of production to the environ- } \\
\text { ment }\end{array}$ & Form & Proactive \\
\hline & - Indicator of external pressures over the company & Form & Proactive \\
\hline & - Index of customer satisfaction & Formula & Proactive \\
\hline \multirow{3}{*}{$\begin{array}{l}\text { Environmental } \\
\text { work conditions }\end{array}$} & - Good practices in logistics and worksite layout & Form & Proactive \\
\hline & - Volume of generated waste & Formula & Proactive \\
\hline & $\begin{array}{l}\text { - NR-17 indicator of adequacy to environmental } \\
\text { conditions on worksites }\end{array}$ & Checklist & Proactive \\
\hline \multirow[t]{6}{*}{ Work efficiency } & - Efficiency in autonomous units sales & Formula & Proactive \\
\hline & - Average productivity of each employee & Formula & Proactive \\
\hline & - Rate of production errors & Formula & Reactive \\
\hline & $\begin{array}{l}\text { - Rate of activities that do not add value to the prod- } \\
\text { uct }\end{array}$ & Formula & Reactive \\
\hline & - Overall work productivity & Formula & Proactive \\
\hline & - Rework index & Formula & Reactive \\
\hline \multirow{3}{*}{$\begin{array}{l}\text { Worksite machines } \\
\text { and tools }\end{array}$} & - Total maintenance cost & Formula & Proactive \\
\hline & $\begin{array}{l}\text { - NR-17 Indicator of machinery and tools adequacy } \\
\text { on worksites }\end{array}$ & Checklist & Proactive \\
\hline & $\begin{array}{l}\text { - NR-18 Indicator of machinery and tools adequacy } \\
\text { on worksites }\end{array}$ & Checklist & Proactive \\
\hline \multirow[t]{2}{*}{ Worksite furniture } & - NR-17 indicator of furniture adequacy & Checklist & Proactive \\
\hline & $\begin{array}{l}\text { - Number of departures due to ergonomically inap- } \\
\text { propriate furniture }\end{array}$ & Formula & Reactive \\
\hline \multirow[t]{18}{*}{ Work organization } & - Repair and replacement of material cost & Formula & Reactive \\
\hline & - Cost on assistance to the insured & Formula & Reactive \\
\hline & - Total cost & Formula & Reactive \\
\hline & - Costs for the period of removal & Formula & Reactive \\
\hline & - Compensation received by the company & Formula & Reactive \\
\hline & - NR-17 indicator of adequacy to work organization & Checklist & Proactive \\
\hline & $\begin{array}{l}\text { - OHSAS } 18001 \text { indication of adequacy to work } \\
\text { organization }\end{array}$ & Checklist & Proactive \\
\hline & - Indicator of employee satisfaction with coworkers & Scale & Proactive \\
\hline & - Indicator of employee satisfaction with supervisors & Scale & Proactive \\
\hline & - Indicator of psychological overload & Form & Proactive \\
\hline & $\begin{array}{l}\text { - Indicator of organizational performance according } \\
\text { to their collaborators }\end{array}$ & Scale & Proactive \\
\hline & - Improvements in work process and technology & Form & Proactive \\
\hline & $\begin{array}{l}\text { - Number of conditions of insecure environment by } \\
\text { sector/workplace }\end{array}$ & Formula & Reactive \\
\hline & - Absenteeism rate & Formula & Reactive \\
\hline & - Turnover rate & Formula & Reactive \\
\hline & - Training rate & Formula & Proactive \\
\hline & - Total of investments in ergonomics actions & Formula & Proactive \\
\hline & $\begin{array}{l}\text { - Total workforce by employment type, employment } \\
\text { contract and region }\end{array}$ & Formula & Proactive \\
\hline
\end{tabular}




\begin{tabular}{|c|c|c|c|}
\hline & $\begin{array}{l}\text { - Monetary value of significant fines and total num- } \\
\text { ber of non-monetary sanctions for non-compliance } \\
\text { with laws and regulations }\end{array}$ & Formula & Reactive \\
\hline \multirow[t]{3}{*}{$\begin{array}{l}\text { Workers Satisfac- } \\
\text { tion }\end{array}$} & $\begin{array}{l}\text { - Actions that enable the contributor a good quality } \\
\text { of life }\end{array}$ & Form & Proactive \\
\hline & $\begin{array}{l}\text { - Indicator of employee's trust towards the organiza- } \\
\text { tion }\end{array}$ & Scale & Proactive \\
\hline & $\begin{array}{l}\text { - OHSAS } 18001 \text { indicator of adequacy to work safe- } \\
\text { ty }\end{array}$ & Checklist & Proactive \\
\hline \multirow[t]{19}{*}{$\begin{array}{l}\text { Workers Health } \\
\text { and Safety }\end{array}$} & $\begin{array}{l}\text { - Statistics of occupational diseases to occupational } \\
\text { activities }\end{array}$ & Formula & Reactive \\
\hline & $\begin{array}{l}\text { - Statistics of occupational diseases by occupational } \\
\text { activity }\end{array}$ & Formula & Reactive \\
\hline & - Incidence of unsafe acts by man/hours worked & Formula & Reactive \\
\hline & $\begin{array}{l}\text { - OHSAS } 18001 \text { indicator of adequacy to work satis- } \\
\text { faction }\end{array}$ & Checklist & Proactive \\
\hline & $\begin{array}{l}\text { - NR-18 indicator of adequacy to workers' health and } \\
\text { safety }\end{array}$ & Checklist & Proactive \\
\hline & $\begin{array}{l}\text { PCMAT indicator of adequacy to workers' health } \\
\text { and safety }\end{array}$ & Form & Proactive \\
\hline & - Rate of personal factors of insecurity & Formula & Reactive \\
\hline & - Number of medical care by workers & Formula & Reactive \\
\hline & $\begin{array}{l}\text { - Average number of days charged due to permanent } \\
\text { disability }\end{array}$ & Formula & Reactive \\
\hline & $\begin{array}{l}\text { - Average number of days lost due to total temporary } \\
\text { disability }\end{array}$ & Formula & Reactive \\
\hline & $\begin{array}{l}\text { - Percentage of impersonal species accidents with } \\
\text { higher incidence }\end{array}$ & Formula & Reactive \\
\hline & - Percentage of impersonal accidents & Formula & Reactive \\
\hline & - Percentages of injury sources with higher incidence & Formula & Reactive \\
\hline & - Percentage of personal accidents & Formula & Reactive \\
\hline & $\begin{array}{l}\cdot \text { Percentage of types of personal accidents with } \\
\text { higher incidence }\end{array}$ & Formula & Reactive \\
\hline & - Frequency rate of accidents with removal injuries & Formula & Reactive \\
\hline & $\begin{array}{l}\text { - Frequency rate of accidents with injuries without } \\
\text { removal }\end{array}$ & Formula & Reactive \\
\hline & • Average time computed & Formula & Reactive \\
\hline & - Accident severity rate & Formula & Reactive \\
\hline \multirow{3}{*}{$\begin{array}{l}\text { Transportation of } \\
\text { Materials }\end{array}$} & - Material circulation index & Formula & Proactive \\
\hline & $\begin{array}{l}\cdot \text { NR-18 indicator of adequacy to loading, transporta- } \\
\text { tion and unloading of materials }\end{array}$ & Checklist & Proactive \\
\hline & $\begin{array}{l}\text { - NR-17 indicator of adequacy to loading, transporta- } \\
\text { tion and unloading of materials }\end{array}$ & Checklist & Proactive \\
\hline
\end{tabular}

\subsection{Detailed SIDECE Model}

All forms and instruments of data collection (column 3) to obtain the indicators have been developed and constituted an operational protocol called (detailed) "SIDECE Model".

The detailed SIDECE was structured with 6 (six) categories of indicators components, taking as reference the systems of indicators listed in item 5.3 of this Article:
Category 1: Name of indicator

Category 2: Goal/Objective

Category 3: Form of data collection

Category 4: Time of data validity

Category 5: Variable(s) of reference

Category 6: Responsible professional

On Table 2 it is presented an indicator and its respective categories. 
Table 2

An example of Indicator according to the detailed SIDECE model

\begin{tabular}{|c|c|c|c|c|c|}
\hline $\begin{array}{l}\text { Name of } \\
\text { indicator }\end{array}$ & Goal/Objective & Form of data collection & Time of data validity & $\begin{array}{l}\text { Variable(s) of } \\
\text { reference }\end{array}$ & $\begin{array}{l}\text { Responsible profes- } \\
\text { sional }\end{array}$ \\
\hline $\begin{array}{l}\text { Percent- } \\
\text { age of } \\
\text { produc- } \\
\text { tion } \\
\text { errors }\end{array}$ & $\begin{array}{l}\text { Check the amount } \\
\text { of errors when } \\
\text { constructing an } \\
\text { edification unit } \\
\text { (tower or build- } \\
\text { ing) and calculate } \\
\text { the percentage of } \\
\text { errors correspond- } \\
\text { ing to each step of } \\
\text { the work }\end{array}$ & $\begin{array}{l}\mathrm{E}(\%) \mathrm{i}=\mathrm{NEi} / \mathrm{NET} \\
\mathrm{E}(\%) \text { : Percentage of produc- } \\
\text { tion errors } \\
\text { NEi: Number of errors found } \\
\text { on the "i" phase when con- } \\
\text { structing a unit } \\
\text { NET: Total number of errors } \\
\text { when constructing a unit }\end{array}$ & $\begin{array}{l}\text { The data regarding the } \\
\text { amount of errors must } \\
\text { be frequently collected } \\
\text { during the work, but } \\
\text { the percentage can } \\
\text { only be calculated at } \\
\text { the end of a con- } \\
\text { structed unit }\end{array}$ & $\begin{array}{l}\text { Ergonomic } \\
\text { costs }\end{array}$ & $\begin{array}{l}\text { The data collection } \\
\text { can be done by train- } \\
\text { ees. The analysis and } \\
\text { disclosure must be } \\
\text { done by the production } \\
\text { manager }\end{array}$ \\
\hline
\end{tabular}

\section{Discussions}

The SIDECE consists of proactive and reactive indicators, and it can be widely applied in building construction companies. This system will be applied in large and medium-sized building construction works in the city of Natal-RN.

During the development of the survey, we realized that indicators of ergonomics need to be integrated with every part of the company. To apply these indicators the company must be willing to properly inform the data needed for research.

The participation and collaboration of the company's employees are of fundamental importance to have an effective SIDECE.

We conclude that in order to establish real changes in the workplace it is necessary to establish in the company an "Organizational Culture in Ergonomics." The mandatory conducts have to be inserted not only in the process, but must also compose the whole culture of the organization.

The research developed to elaborate this system of indicators aimed at contributing to the maturation of the building construction industry, by integrating socio-technical criteria ${ }^{[7]}$ for the construction of indicators that will help in the analysis and management decision-making of companies in this industry.

\section{References}

[1] Wisner, Alain. Por dentro do trabalho: ergonomia, método e técnica. Tradução Flora Maria Gomide Vezzá. São Paulo: FTD/Oboré, 1987;

[2] Brasil, Ministério do Trabalho e Emprego, Anuário Estatístico de Acidentes do Trabalho, 2009.
[3] Kaplan, Robert S.; Norton, David P. A estratégia em ação: balanced socorecard. Rio de Janeiro: Elsevier, 1997. 348 p;

[4] Nogueira, Francisco Eugenio. A importância de indicadores ergonômicos nos prêmios de qualidade. Revista Ação Ergonômica, v. 1, n. 3, p. 65-71, 2002. Disponível em: $<$ artigocientifico.com.br/uploads/artc_1147808851_58.doc $>$. Acesso em 02 jun. 2010;

[5] IEA. What is Ergonomics. 2000 $<$ http://www.iea.cc/01 what/What $\% 20$ is\%20Ergonomics.html $>$ Acesso em: 29 set 2011;

[6] Human Factors and Ergonomics Society apud Hendrick, Hal W.; Kleiner, Brian M. Macroergonomia: uma introdução aos projetos de sistemas de trabalho. Rio de Janeiro: Virtual Científica, 2006, p. 16;

[7] Hendrick, Hal W.; Kleiner, Brian M. Macroergonomia: uma introdução aos projetos de sistemas de trabalho. Rio de Janeiro: Virtual Científica, 2006;

[8] Silva, Edna Lúcia da; Menezes, Estera Muszkat. Metodologia da Pesquisa e Elaboração de Dissertação, 2001;

[9] Câmara Brasileira da Indústria da Construção (CBIC). Relatório 2003/2004 da Comissão de Economia e Estatística CEE. Disponível em: $<$ http://www.cbicdados.com.br/files/anuario/relatorio.pdf $>$. Acesso em: 29 set 2011;

[10]Federação das Indústrias do Rio Grande do Norte (FIERN). Cadastro Industrial. $<$ http://cadindustrial.fiern.org.br/consulta.php $>$. Acesso em: 30 set 2011;

[11] Costa, Dayana Bastos. Diretrizes para a concepção, implementação e uso de sistemas de indicadores de desempenho para empresas de construção civil. 2003. $174 \mathrm{f}$. Dissertação (Mestrado em Engenharia) - Programa de PósGraduação em Engenharia Civil, Universidade Federal do Rio Grande do Sul, Porto Alegre, 2003;

[12] Navarro, Gustavo Pedroso. Proposta de sistema de indicadores de desempenho para a gestão da produção em empreendimentos de edificações residenciais. Dissertação (Mestrado em Engenharia) - Escola de Engenharia, UFRGS, Porto Alegre, 2005;

[13]Diário Oficial da União, Portaria GM nº 3.214, de 08.06.78, do Ministério do Trabalho e Emprego: Norma Regulamentadora NR 18 (Condições e meio ambiente de trabalho na indústria da construção). Diário Oficial da União, 06. jul. 1978 .

[14]Diário Oficial da União, Portaria GM n ${ }^{\circ} 3.214$, de 08.06.78, do Ministério do Trabalho e Emprego: Norma 
Regulamentadora NR 17 (Ergonomia). Diário Oficial da União, 06. jul. 1978.

[15] Siqueira, Mirlene Maria Matias (Org.). Medidas do comportamento organizacional: ferramentas de diagnóstico e de gestão. Porto Alegre: Artmed, 2008. 344 p.;

[16]Cardoso, Vinícius Carvalho; Macieira, André Rego; Jesus, Leandro dos Santos de; Lengler, Gustavo Maltez. Indicadores para gestão de competências: uma abordagem baseada em processos. Disponível em: <http://www.gpi.ufrj.br/pdfs/artigos/Cardoso,\%20Macieira,\% 20Jesus, \%20Lengler\%20-

$\% 20$ Indicadores $\% 20$ para $\% 20$ Gestao $\% 20 \mathrm{de} \% 20$ Competencias \%20-\%20XXII\%20ENEGEP\%20-\%202002.pdf>. Acesso em 30 set. 2011 ;

[17] V Conferência Nacional da Felidade Interna Bruta. Perguntas e respostas sobre felicidade. Disponível em: $<$ http://www.visaofuturo.org.br/pdfs2/Sugestões\%20para $\% 20$ a \%20Implementação\%20do\%20FIB.pdf>. Acesso em 20 nov. 2010. Gross National Happiness (FIB);

[18]França, Ana Cristina Limongi. Indicadores empresariais de qualidade de vida no trabalho: esforço empresarial e satisfação dos empregados no ambiente de manufaturas com certificação ISO 9000. . Tese (Doutorado em Administração) - Faculdade de Economia, Administração e Contabilidade, Universidade de São Paulo, São Paulo, 1996, 355 p.;
[19]Associação Brasileira de Normas Técnicas (ABNT). NBR 14280: Cadastro de acidente de trabalho - Procedimento e classificação. Rio de Janeiro, 2001. bairro Belo Horizonte, Itapetininga, SP 2009. Disponível em: $<$ http://www.visaofuturo.org.br/pdfs2/Descrição\%20do\%20Pr ojeto\%20Piloto\%20Itapetininga.pdf>. Acesso em 20 nov. 2010. Norm $n^{\circ} 14280: 2000$

[20]OHSAS 18001:2001. Sistema de Gestão de Segurança e Saúde Ocupacional. BSI.

[21]Barkokébas Junior, Béda; Véras, Juliana C.; Lago, Eliane Maria G.; Rabbani, Emilia Rahnemay Kohlman. Indicadores de segurança do trabalho para direcionamento do sistema de gestão de segurança e saúde no trabalho. In: Encontro Nacional de Engenharia de Produção, 26. Fortaleza, CE. Fortaleza: UFC, 2006. Disponível em: $<$ http://www.abepro.org.br/biblioteca/ENEGEP2006_TR5003 36 8432.pdf>. Acesso em 29 set. 2010;

[22] Diretrizes para Relatório de Sustentabilidade. Global Reporting Initiative (GRI), Amsterdan, 2000-2007. Disponível em: $<$ http://www.globalreporting.org/NR/rdonlyres/4855C490A872-4934-9E0B-

8C2502622576/2725/G3_POBR_RG_Final_with_cover.pdf>. Acesso em 29 set. 2011. 